\title{
PECULIARITIES OF COMPOSITION OF COARSE PERIDOTITE XENOLITHS OF SOME KIMBERLITE PIPES FROM SOURTH AFRICA
}

\author{
E.V. Malygina, N.P. Pokhilenko \\ Institute of Geology and Mineralogy, SB RAS, Novosibirsk, Russia
}

\section{INTRODUTION}

Detailed study of the collection of mantle xenoliths from the kimberlites of South Africa has continued the earlier series of studies on the Kapvaal craton mantle xenoliths (South Africa) and their analogs from the Udachnaya kimberlite pipe (Yakutia) (Boyd, 1987; Pokhilenko et al., 1993; Pokhilenko, 2009; Pearson et. al., 1995; Boyd, Pokhilenko et al.,1997; Malygina et al., 2003). Comparative analysis of the results of study of coarse garnet-spinel peridotites from the Kapvaal craton and Siberian Platform demonstrates some differences both in the interval of rocks variations and in their structural peculiarities along with the similarity of chemical composition of minerals and rocks. Higher pressure values are found for coarse peridotite xenoliths from the Udachnaya pipe and temperature range is almost the same. Peculiarities of the isotopic composition variations and geochemical characteristics show that peridotites of the Siberian Platform and South Africa have suffered multi- stage metasomatism after joining the lithosphere. Metasomatism is manifested in the significant addition of $\mathrm{Ti}, \mathrm{Si}, \mathrm{Al}, \mathrm{Fe}, \mathrm{K}, \mathrm{Na}$, $\mathrm{H}_{2} \mathrm{O}$ and $\mathrm{CO}_{2}$. A comprehensive comparative study of coarse peridotite xenoliths from these regions helps to reveal the peculiarities of formation and evolution of mantle ultrabasic rocks and to understand the complex processes of mineral formation in the upper parts of the lithosphere mantle of the central areas of Siberian Platform and South Africa.

\section{METHODS}

137 samples of peridotite xenoliths from the Bells Bank and Roberts Victor kimberlite pipes from South Africa and Kimberly Dump, Wesselton Kimberly and Bostoff Road have been studied. Rock chemical composition has been determined by X-ray fluorescence method with the use of X-ray fluorescence spectrometer ARL9900-XP. The composition of minerals has been studied using electron microprobe Jeol Super Probe 7800 .

The content of REE and trace elements in garnet and coexisting monoclinic pyroxenes from 25 most representative samples has been determined by laserablation with the use of mass spectrometer Thermo Scientific XSeries 2 ICP-MS. Morphology, phase and chemical composition of some typical grains have been studied with the use of scanning electron microscope LEO1430VP equipped the energy spectrometer "Oxford”.

\section{PETROGRAPHY}

The coarse peridotites are most often represented by initially rounded close to isometric xenoliths ranging in size from 4 to $26 \mathrm{~cm}$. Primary mantle minerals (garnet, clinopyroxene, 


\section{$10^{\text {th }}$ International Kimberlite Conference, Bangalore - 2012}

spinellids) in the outer zones of xenolith, which have experienced the near surface transformations, are not changed and still retained. Both fresh and serpentinized rocks in which primary olivine and orthopyroxene are replaced by the secondary minerals are observed in the collection.

Coarse garnet lherzolites and harzburgites (often with elevated proportion of modal enstatites) are most widespread rocks and amount $69 \%$ in the studied collection of xenoliths. Spinel lherzolite and ilmenite peridotite xenoliths are most rare (22\% and 5\%, respectively). Ilmenitecontaining peridotites are represented dominantly by ilmenite and ilmenite-pyrope varieties. Ilmenite- chromite lherzolites are rare. A proportion of garnet-spinel lherzolites is significantly lower - about $4 \%$ of the studied xenoliths. Phlogopite is typical of a half of the studied mantle xenoliths from South Africa. Phlogopite content changes from individual small rounded grains to large structurally balanced packs and crystals, which make up to $50 \%$ of the rock volume.

Rutile, perovskite, hematite, magnetite, Nisulfides and crishtonites are found as accessory minerals in peridotite xenoliths from the Kimberly Dump and the Wesselton Kimberly. The accessory graphite is found in single peridotite xenoliths. Secondary minerals are represented by serpentine, amphibole, hematite, magnetite, calcite and quartz.

Extensive metasomatic changes are characteristic of the studied peridotites from South Africa. This is manifested in the extensive development of phlogopitization process and is confirmed by the presence of various accessory minerals. Mica forms the intergrowth structures with pyroxenes or completely replaces the primary flattened enstatite crystals. Phlogopitization processes are developed widely in the peridotites of the Kimberly Dump, the Wesselton Kimberly and the Bells Bank as compared to the xenoliths of the Bostoff Road. The zones of plastic deformations are often observed in the Kimberly Dump peridotites. The areas with recrystallized fine grained olivines, covering the significant parts of the rock, have been found in some Kimberly Dump and Bostoff Road xenoliths. The Bells Bunk peridotite xenoliths are dense almost black rocks, characterized with substantial serpentinization of primary minerals. Garnet grains of different compositions and parageneses (lherzolite and harzburgite-dunite) have been observed in several garnet and garnet-spinel harzburgite xenoliths. Reaction macro- and micro intergrowth structures formed by Cr-spinel, pyroxenes and garnet are often observed in the Kimberly Dump spinel and garnet-spinel lherzolites. Interrupted rims of spinel around enstatites, oriented lamella of monoclinic pyroxene in the rhombic pyroxene, garnet inclusions of different morphology in the enstatites and continuous and discontinuous clino- and orthopyroxene rims around the garnet are observed. Ilmenite-chromite lherzolites have been established among the Kimberly Dump xenoljths along with the ilmenite and garnetilmenite peridotites and websterites of the Bostoff Road, the Kimberly Dump and the Wesselton Kimberly. They are usually represented by sheared peridotites with signs of metasomatism and partial melting.

\section{MINERAL COMPOSITION}

According to the microprobe analyses all primary minerals of the studied coarse peridotites of South Africa except for garnet are nearly homogenous within xenolith.

Olivines from the studied rocks have high Mg-content (Mg\#=[100Mg/(Mg+Fe)] 88,393,6\%). Ca admixture is 0,001-0,09 wt\% $\mathrm{CaO}$ that can be related to comparatively low temperature values of the rock equilibrium or the high pressures of their formation. The chrome admixture doesn't exceed $0,05 \mathrm{wt} \%$ in contrast to the Udachnaya pipe lherzolites where $\mathrm{Cr}_{2} \mathrm{O}_{3}$ content in the olivines of chromite- containing 


\section{$10^{\text {th }}$ International Kimberlite Conference, Bangalore - 2012}

rocks reaches 0,09 wt\% (Sobolev et. al., 2009). $\mathrm{Ni}$ admixture $(0,196-0,425 \mathrm{wt} \% \mathrm{NiO})$ correlates with the total Mg-content of the studies rocks.

Orthopyroxenes from the Kimberly Dump, the Bostoff Road and the Roberts Victor contain $89-94 \%$ of enstatites minal, Mg\# varies within the range $86,8-94,8 \%$. The Wesselton Kimberly rhombic pyroxenes are distinguished by Mg\# values 93\% and enstatite minal variations 85-99\%. The $\mathrm{Al}$ admixture in the orthopyroxenes from spinel peridotites of the Kimberly Dump and Bostoff Road varies within the range 0,01-2,90 wt $\% \mathrm{Al}_{2} \mathrm{O}_{3}$, Cr is 0,014-0,89 wt $\% \mathrm{Cr}_{2} \mathrm{O}_{3}$. Enstatites with low $\mathrm{Al}\left(0,01-0,69 \mathrm{wt} \% \mathrm{Al}_{2} \mathrm{O}_{3}\right)$ and $\mathrm{Cr}(0,01-$ $0,35 \mathrm{wt} \% \mathrm{Cr}_{2} \mathrm{O}_{3}$ ) content have been found in the garnet-, garnet-ilmenite, ilmenite and garnetspinel rocks. Similar enstatites from the Wesselton Kimberly contain 0,22-3,88 wt\% $\mathrm{Al}_{2} \mathrm{O}_{3}$ and 0,17$0,83 \mathrm{wt} \% \mathrm{Cr}_{2} \mathrm{O}_{3}$; and 0,57-2,05 wt $\% \mathrm{Al}_{2} \mathrm{O}_{3}$ and 0,23-0,45 wt\% $\quad \mathrm{Cr}_{2} \mathrm{O}_{3}$ respectively. Orthopyroxenes of spinel peridotites are more aluminous and contain more AlIV as compared to the enstatites from garnet- and ilmenitecontaining peridotites. The $\mathrm{Ca}$ and $\mathrm{Na}$ admixtures are found in all enstatites. The Ca admixture is 0,01-1,07 wt\% $\mathrm{CaO}$ for peridotites of the Kimberley Dump, 0,25-0,80 wt\% $\mathrm{CaO}$ for the Bostoff Road xenoliths, 0,48 wt\% $\mathrm{CaO}$ for the Roberts Victor lherzolites and 0,12-2,98 wt\% CaO for rocks of the Wesselton Kimberley. The Na admixture is $0,02-0,19 \mathrm{wt} \% \mathrm{NaO}$ in peridotites of the Kimberley Dump, Bostoff Road and Roberts Victor and 0,01-0,66 wt\% $\mathrm{NaO}$ in the Wesselton Kimberley xenoliths.

Clinopyroxenes are represented by $\mathrm{Cr}$ diopsides with variable content of $\mathrm{Cr}_{2} \mathrm{O}_{3}, \mathrm{NaO}$ and $\mathrm{K}_{2} \mathrm{O}$. Clinopyroxenes from the Kimberly Dump xenoliths contain 0,13-3,86 wt\% $\mathrm{Cr}_{2} \mathrm{O}_{3}$, $0,10-3,40 \mathrm{wt} \% \mathrm{Na}_{2} \mathrm{O}$ and $0,01-0,15 \mathrm{wt} \% \mathrm{~K}_{2} \mathrm{O}$. The following values have been obtained for clinopyroxenes from the Bostoff Road, Bells Bank and Roberts Victor peridotites: 40-3,69 wt\% $\mathrm{Cr}_{2} \mathrm{O}_{3}, 1,10-3,37$ wt $\% \mathrm{Na}_{2} \mathrm{O}$ 0,01-0,86 wt $\% \mathrm{~K}_{2} \mathrm{O}$.
The Wesselton Kimberly clinopyroxenes are characterized by $0,83-2,98 \mathrm{wt} \% \mathrm{Cr}_{2} \mathrm{O}_{3}, 1,11-3,35$ wt $\% \mathrm{Na}_{2} \mathrm{O} \quad 0,60$ wt $\% \mathrm{~K}_{2} \mathrm{O}$ contents.

Significant $\mathrm{Na}$ undercompensation of trivalent cations is distinguished in the clinopyroxenes from the Kimberly Dump, Bostoff Road and Wesselton Kimberly spinel and garnetspinel peridotites. This fact reflects the presence of elevated admixture of chermakite component in their composition. Climopyroxenes from the Kimberly Dump garnet and spinel peridotites are distinguished by the increased $\mathrm{Fe} \#=[100 \mathrm{Fe} /$ (Fe+Mg)] compose 4,6-10,4\%. The Fe\# value reaches $17,1 \%$ in the ilmenite-containing varieties of the Kimberly Dump. The Fe\# value of clinopyroxenes from the Bostoff Road, Wesselton Kimberly and Roberts Victor peridotite xenoliths are within the smaller limits (Fe\# 5,33-9,07\%).

Garnets from the coarse peridotite xenoliths of South Africa relate mainly to chromium pyropes (Cr2O3 up to 8,37 wt\%, $\mathrm{CaO} 3,77-6,52 \mathrm{wt} \%$ ) and form a trend which corresponds to lherzolite paragenesis. The garnets of harzburgite-dunite paragenesis with $\mathrm{CaO}$ 1,49-3,55 wt\% and $\mathrm{Cr}_{2} \mathrm{O}_{3}$ $4,81-7,45 \mathrm{wt} \%$ have been found in several xenoliths. Pyropes from the most deep-seated chromite- pyrope harzburgites fall within the field of pyropes associated with diamond (Sobolev, 1977). The Ti admixture at an average $0,07 \mathrm{wt} \%$ $\mathrm{TiO}_{2}$ in the lilac-purple garnets reaching 0,37 wt $\%$ $\mathrm{TiO}_{2}$ in the orange garnet from the Bells Bank dunite. The stable isomorphic impurity of $\mathrm{Na}$ (up to $0,10 \mathrm{wt} \% \mathrm{Na}_{2} \mathrm{O}$ ) is found in the majority of orange garnets, that is essential for the garnets from ultrabasic paragenesis. Na-content directly correlates with $\mathrm{Ca}$, Ti and Fe-content of garnets notably with the increase of mafic components. This fact can support a significant role of metasomatic processes in the upper mantle in these regions of South Africa. In a number of the Bells Bank and Kimberley Dump xenoliths there are: a) garnets with wide variations of chemical composition, corresponding to different mantle parageneses - harzburgite-dunite and lherzolite; 


\section{$10^{\text {th }}$ International Kimberlite Conference, Bangalore - 2012}

b) garnets with variations in $\mathrm{Cr}$ and Ca-contents within lherzolite trend.

Compositional variations of spinellides from the Kimberly Dump peridotites are: $\mathrm{Al}_{2} \mathrm{O}_{3}$ 0,32-28,9 wt\% and $\mathrm{Cr}_{2} \mathrm{O}_{3} 41,4-68 \mathrm{wt} \%$, from the Bostoff Road peridotites $-\mathrm{Al}_{2} \mathrm{O}_{3} 1,11-21,9 \mathrm{wt} \%$ and $\mathrm{Cr}_{2} \mathrm{O}_{3}$ 46,7-65,7 wt\%, from the Bells Bank peridotites $-\mathrm{Al}_{2} \mathrm{O}_{3} 4,14-9,74 \mathrm{wt} \%$ and $\mathrm{Cr}_{2} \mathrm{O}_{3} 60$,8$61,8 \mathrm{wt} \%$, from the Wesselton Kimberley peridotites - $\mathrm{Al}_{2} \mathrm{O}_{3} 3,96-19,2$ wt\% è $\mathrm{Cr}_{2} \mathrm{O}_{3} 45,6$ $58,1 \mathrm{wt} \%$. Spinellides from the studied xenoliths are divided into two groups. The first group is alumina spinels from the garnet-free and garnetspinel low temperature coarse lherzolites from the Kimberly Dump, the Bostoff Road and the Wesselton Kimberly pipes. Elevated $\mathrm{Al}_{2} \mathrm{O}_{3}$ 17,728,9 wt\%, low $\mathrm{Cr}_{2} \mathrm{O}_{3} 40,2-50,0$ wt\% and the lowest TiO2 (up to $0,02 \mathrm{wt} \%$ ) are typical of them. The second group consists of chromites from high$\mathrm{Cr}$ and low-Al chromite and garnet- chromite peridotites and harzburgites and ilmenite-spinel peridotites of the Kimberly Dump, the Bostoff Road, the Bells Bank and the Wesselton Kimberly. They contain 0,51-10,9 wt\% $\mathrm{Al}_{2} \mathrm{O}_{3}$ and 49,5-68,0 wt $\% \mathrm{Cr}_{2} \mathrm{O}_{3}$. $\mathrm{TiO}_{2}$ varies from 0,01 to $3,26 \mathrm{wt} \%$. All spinellides are magnesian spinellides - 20,5$60 \% \mathrm{Mg}$, average value $\mathrm{Mg \#}$ is $48,4 \%$. In the average Al- spinels from the Kimberly Dump spinel peridotites are less magnesian.

Ilmenites are characterized by very wide variations in magnesium and iron content - 7,6415,7 wt\% $\mathrm{MgO}$ and 25,4-40,3 wt\% FeO, and relatively narrow variations in chromium and titanium content - 0,22-3,90 wt $\% \mathrm{Cr}_{2} \mathrm{O}_{3}$ and 48,455,1 wt\% TiO2. Ilmenites from the Wesselton Kimberly peridotites have higher Mg (12,7-15,7 wt\% MgO) and Ti (48,4-52,3 wt\% $\mathrm{TiO}_{2}$ ) content as compared to the Kimberly Dump and Bostoff Road ilmenites - 7,64-11,4 wt\% MgO è 53,0-55,1 wt\% $\mathrm{TiO}_{2}$. This points to the essential change in the relationships of geikielite and hematite minals in the composition of the compared ilmenite groups: 32,7-61,8\% and 3,6$11,3 \%$, respectively.
Phlogopites are distinguished by low titanium (up to 3,14 wt $\% \mathrm{TiO}_{2}$ ), chromium $(0,02-$ $1,30 \mathrm{wt} \% \mathrm{Cr}_{2} \mathrm{O}_{3}$ ) and iron (1,66-7,99 wt\% $\left.\mathrm{FeO}\right)$ concentrations. $\mathrm{NiO}$ content in micas varies from 0,05 to $0,30 \mathrm{wt} \%, \mathrm{BaO}$ impurity reaches $0,33 \mathrm{wt} \%$. Regularly conjugated change of Fe-content of coexisting phlogopite and garnet has been found for the majority of xenoliths, this is evidence of the "primary" nature of phlogopite (Dawson, Smith, 1975).

Rutile composition is $94,8 \mathrm{wt} \% \mathrm{TiO}_{2}, 0,20$ wt\% $\mathrm{FeO}$ and elevated amounts of $\mathrm{Cr}_{2} \mathrm{O}_{3}$ $3,40 \mathrm{wt} \%$. In general this corresponds to that from the mantle xenoliths of South Africa studied earlier (McGetchin, Silver, 1970; Smith, Dawson, 1975).

Minerals of the crichtonites series from the Kimberly Dump and the Wesselton Kimberly (Table1) are similar to the described compositions of metasomatic crichtonites "LIMA" (Haggerty, 1983).

Table-1. Representative chemical compositions of crichtonites from peridotite xenoliths of Sourth Africa

\begin{tabular}{lcc} 
Coarse Xenoliths & Kimberley Dump Wesselton Kimberley \\
\hline $\mathrm{TiO}_{2}$ & 57,6 & 59,4 \\
$\mathrm{Al}_{2} \mathrm{O}_{3}$ & 0,22 & 0,91 \\
$\mathrm{Cr}_{2} \mathrm{O}_{3}$ & 17,5 & 14,0 \\
$\mathrm{La}_{2} \mathrm{O}_{3}$ & $<0,01$ & 0,20 \\
$\mathrm{Ce}_{2} \mathrm{O}_{3}$ & 1,57 & 1,80 \\
$\mathrm{FeO}_{2}$ & 9,86 & 10,4 \\
$\mathrm{MnO}$ & 0,10 & 0,07 \\
$\mathrm{MgO}$ & 3,47 & 3,80 \\
$\mathrm{CaO}$ & 0,46 & 0,72 \\
$\mathrm{BaO}$ & 2,21 & 2,08 \\
$\mathrm{SrO}_{2}$ & 2,06 & 1,81 \\
$\mathrm{ZO}_{2}$ & 4,10 & 4,46 \\
$\mathrm{ThO}_{2}$ & 0,03 & 0,04 \\
$\mathrm{Nb}_{2} \mathrm{O}_{5}$ & 0,07 & 0,11 \\
$\mathrm{Na}_{2} \mathrm{O}$ & 0,01 & 0,05 \\
$\mathrm{Total}^{2}$ & 99,3 & 99,6 \\
\hline
\end{tabular}

Perovskite from the Wesselton Kimberly ilmenite peridotite has the following composition: $\mathrm{TiO}_{2} 55,2 \mathrm{wt} \%, \mathrm{Al}_{2} \mathrm{O}_{3}$ 0,31 wt $\%, \mathrm{La}_{2} \mathrm{O}_{3} 0,38 \mathrm{wt} \%$, $\mathrm{Ce}_{2} \mathrm{O}_{3} 2,06 \mathrm{wt} \%$, FeO 2,53 wt\%, MnO 0,09 wt\%, $\mathrm{CaO} 36,8$ wt\%, BaO 0,13 wt\%, ZrO20,19 wt\%, $\mathrm{Nb}_{2} \mathrm{O}_{5}$ 0,66 wt\% $\mathrm{Na}_{2} \mathrm{O}$ 0,61 wt\%. 


\section{$10^{\text {th }}$ International Kimberlite Conference, Bangalore - 2012}

Sulfides are distinguished by wide compositional variations not only of different grains but within the limits of one grain. For example, Ni 45-72,5, S 26,9-31,1, Co 0-14,5, Fe 0,63-7,54, up to $\mathrm{Cu} 0,8$.

\section{PETROLOGY}

The peculiarities of chemical composition of the most fresh and large coarse peridotite xenoliths from the Kimberly Dump and the Bostoff Road are evidence that the mantle matter is essentially enriched in basite component if compare with those from Siberian kimberlites (Boyd et. al., 1997). The rocks are characterized by the elevated alumina $\left(\mathrm{Al}_{2} \mathrm{O}_{3}\right.$ up to $\left.9,97 \mathrm{wt} \%\right)$, titanium $\left(\mathrm{TiO}_{2}\right.$ up to $\left.3,41 \mathrm{wt} \%\right)$, calcium ( $\mathrm{CaO}$ up to $5,78 \mathrm{wt} \%$ ) and potassium ( $\mathrm{K}_{2} \mathrm{O}$ up to $9,07 \mathrm{wt} \%$ ) contents. The iron content varies in the wide limits - 6,56-12,8 wt\% FeO. The stable impurities of barium (up to 0,08 wt\% $\mathrm{BaO}$ ), phosphorus (up to $0,16 \mathrm{wt} \% \mathrm{P}_{2} \mathrm{O}_{5}$ ), vanadium (up to $0,04 \mathrm{wt} \% \mathrm{~V}_{2} \mathrm{O}_{5}$ ) and sulfur $\left(0,04-0,33 \mathrm{wt} \% \mathrm{SO}_{3}\right)$ have been found. The comparison of data on the total chemical composition of peridotite xenoliths from the studied collection with the low temperature peridotites from the Udachnaya pipe has shown the similarity of the same Mg\# olivine values of the mantle rock (88,3-93,6 and 88,4-93,7\% respectively), the overlap of $\mathrm{Ca}$ and $\mathrm{Al}$ trends, $\mathrm{CaO}$ and $\mathrm{Al}_{2} \mathrm{O}_{3}$ inverse relationship vs. $\mathrm{MgO}$ for both of them and $\mathrm{NiO}$ vs. $\mathrm{MgO}$ positive correlation.

A combined temperature interval for the granular peridotites with the coexisting garnet and chrome spinellide is 870-1360î̃ and pressure interval is 20-60 kbar. PT- estimations have been obtained with the use of Brey, Kohler (1990) thermobarometer.

The character of distribution of some of the most important trace and REE in the coexisting pyropes and diopsides shows the complexity of the mantle rocks genesis. Wide variations of REE concentrations are typical for the studied garnets and clinopyroxenes. Elevated LREE concentrations in garnets point to essential secondary enrichment of the rocks. The degree of metasomatic transformations increases with increase depth of rock formation. Basing on the identity of the REE distribution spectra, the moderate differentiation of mantle material in the place of the kimberlite pipes location may be suggested.

\section{CONCLUSION}

The comparison of the obtained results with the same for coarse peridotites from the Udachnaya kimberlite pipe (Yakutia) allows to make the following conclusions:

The elevated contents of modal enstatite in the South African xenoliths confirm the less depletion of mantle material under South Africa as compared with the mantle xenoliths of the Siberian Platform.

Significant variations in the chemical composition of the same name minerals (except garmet) within one xenolith have not been revealed in the peridotites of South Africa, whereas several types of inhomogeneities in garnets, pyroxenes and Cr-spinellides have been found in some part of peridotite xenoliths from the Udachnaya pipe.

The comparative analysis of Yakutian coarse peridotite xenoliths and similar rocks from South Africa has shown that the association of Cr-pyrope + chromite is typical of the lithospheric mantle of the Siberian Platform but its development is relatively rare among the mantle analogs from South Africa.

The peculiarities of chemical composition of coarse peridotites from the Kimberly Dump and the Bostoff road confirm the greater enrichment of the mantle matter in $\mathrm{Ti}, \mathrm{Al}, \mathrm{Ca}, \mathrm{K}, \mathrm{Ba}$ and REE under the studied kimberlites. Occurrence of phlogopite as a rock forming mineral and other accessory minerals indicate of the extensive development of metasomatic treatments.

The processes of formation and evolution of coarse peridotites assume partial melting of the 


\section{$10^{\text {th }}$ International Kimberlite Conference, Bangalore - 2012}

primitive mantle matter and multi stage secondary enrichment with the K-metasomatism prevalence.

\section{References}

Boyd F.R. (1987) High- and low-temperature garnet peridotie xenoliths and their possible relation to the lithosphere- asthenosphere boundary beneah southern Africa. Mantle xenoliths, P.H. Nixon (ed). John Wiley \& Sons Ltd. p.403- 412.

Boyd, F.R., Pokhilenko, N.P., Pearson, D.G. et al (1997) Composition of the Siberian craton mantle: evidence from Udachnaya peridotite xenoliths. Contrib. Mineral. Petrol., 128, pp. 228-246.

Brey G.P., Kohler T., 1990. Geothermobaromerty in four-phase lherzolites II. New thermobarometers, and practical assessment of existing thermobarometers . J. of Petrology, v.31, No.6, pp.1353-1378.

Haggerty S.E. (1983) The mineral chemistry of new titanate from the Jagersfountein kimberlite, South Africa: Implications for metasomatism in the upper mantle. GCA, v.47, No.11, pp. 1833-1854.

Malygina E., Pokhilenko N., Sobolev N. (2003) Coarse peridotite xenoliths of Udachnaya kimberlite pipe, Yakutia: garnetization of peridotites of the Central Siberian platform lithospheric mantle. 8th International Kimberlite conference, Victoria, BC, Canada, June 22-27th: Extended Abstracts, FLA_0191, CD-ROM.

McGetchin T.R., Silver L.T. (1970) Composition relations in minerals from Kimberlite and related rocks in the Moses Rock Dyke, San Juan Country,
Utah. Amer. Mineral, v. 55, pp. 1738-1771.

Pearson D.G., Shirey S.B., Carlson R.W. et. al. (1995) Re-Os, Sm- Nd and Rb-St isotope evidence for thick Archaean lithosphere mantle beneath the Siberian craton modified by multistage metasomatism. Geohim. Cosmohim. Acta, v.59, pp.959-978.

Pokhilenko, N.P., Sobolev, N.V., Boyd, F.R. et al. (1993) Megacrystalline pyrope peridotites in lithosphere of Siberian platform: mineralogy, geochemical peculiarities and problem of origin. Geol. Geophis., v.1, pp.71-84 (in Russian).

Pokhilenko N.P. (2009) Polymict breccia xenoliths: Evidence for the complex character of kimberlite formation. Lithos. 9th International Kimberlite Conference Johann Wolfgang Goethe-University, Frankfurt, Germany 10-15 August 2008, v. 112, No. 2 Supplement, pp. 934-941.

Smith J.V., Dawson J.B. (1975) Chemistry of Ti-poor spinels, ilmenites and rutiles from peridotites and eclogite xenoliths. Phys. Chem. Earth, v. 9, pp.309-322.

Sobolev, N.V. (1977) Deep-seated inclusions in kimberlites and problem of composition of the (8) upper mantle. Washington, D.C., American Geophysical Union, 279 p.

Sobolev, N.V., Logvinova, A.M., Zedgenizov, D.A. et. al. (2009) Petrogenetic significance of minor elements in olivi from diamonds and peridotite xenoliths from kimberlites of Yakutia. Lithos, 9th International Kimberlite Conference Johann Wolfgang Goethe-University, Frankfurt, Germany 10-15 August 2008, v.112, No. 2 Supplement, pp.701-713. 